\title{
Effects of Facebook Collaborative Writing Groups on ESL Undergraduates' Writing Performance
}

\author{
Siti Shuhaida Shukor \\ Faculty of Educational Studies, Universiti Putra Malaysia \\ 43400 Serdang, Selangor, Malaysia \\ E-mail: sitishuhaida@gmail.com \\ Nooreen Noordin (Corresponding author) \\ Faculty of Educational Studies, Universiti Putra Malaysia \\ 43400 Serdang, Selangor, Malaysia \\ E-mail: nooreen@upm.edu.my
}

Received: June 16, 2014 Accepted: June 26, 2014 Published: June 26, 2014

doi:10.5296/ijele.v2i2.5868 URL: http://dx.doi.org/10.5296/ijele.v2i2.5868

\begin{abstract}
This study investigated the effects of Facebook collaborative writing groups on ESL undergraduates writing performance. A total of 33 second year ESL students were involved in this study. The students were divided into two groups; control and experimental groups. Facebook, as the treatment in this study was compared to a conventional method; face-to-face in the collaborative writing activities. The comparison between face-to-face and Facebook collaborative writing groups were made in order to measure students' writing performance on the intervention based on Jacob's et al. (1981) ESL Composition Profile; content, organisation, vocabulary, language us and mechanics. Before using this approach, a pre-test was administered to all students and based on the preliminary results; students were divided into Facebook and face-to-face collaborative writing groups. After using both approaches, a post-test was given to participants in both groups. The data were then analysed using inferential statistics; independent t-test and paired sample t-test. From the findings, it was found that participants in Facebook collaborative writing groups displayed slightly higher scores compared to face-to-face collaborative writing groups. However, the differences between Facebook and face-to-face collaborative writing groups were not significant in the post-test writing scores. When comparison was made within each group, this study found that
\end{abstract}


there were significant differences for overall writing performance, content, organisation, vocabulary, language use and mechanics. Meanwhile in the face-to-face collaborative writing groups, there were also significant differences for overall writing performance, content, organization and vocabulary except for language use and mechanics.

Keywords: Web 2.0, Network-based Language Teaching, Social Network, Computer Assisted Language Learning, Collaborative Writing, Facebook

\section{Introduction}

One of the highly used internet-based forms of communication, social media has offered huge opportunities for users to share information, create conversations and develop their own content of interest conveniently. There are many example of these platforms for instance blogs (wordpress, blogspot), microblogs (Twitter, Posterous, Tumblr), wikis (Wikipedia, Scholarpedia), Social networking sites (Facebook, Academia, Linkedln), photosharing sites (Instagram, Cymera), instant messaging (Whatsapp, WeChat, LINE), video-sharing sites (Keek, Youtube) and many more. These platforms have benefited billions of users from all over the world either from individual perspective, professional level, companies or institutions. From the education perspective, many scholars have found that these platform especially the social networking sites have enormous potential that can encourage critical engagement in discussion as well as harness peer feedback throughout the learning process (Selwyn, 2009).

The most popular social networking site, Facebook has millions of users worldwide. Many features such as the 'like' button, comment application and sharing button in Facebook have attracted users to create discussion and share their thoughts instantly. In line with Facebook tagline 'giving people the power to share and making the world more open and connected' creates space for autonomy and engagement in exchanging ideas and knowledge due to active roles consumed by learners (Lee, Mcloughlin \& Chan, 2008; Ashton \& Newman, 2006). In Facebook, users can have their own group of interests and share and exchanges messages between them via the available applications easily (Kwong, 2007). One of the available applications is 'My Notes' provide users with opportunities to write and blog almost anything under the sun (Kwong, 2007).

Similar to online discussion boards, users can get synchronous or asynchronous feedback from the status or questions posted on their timeline. With such features, the Ministry of Higher Education and Ministry of Education highly encourage the education stakeholders in education to take advantage the benefits of the technologies in language learning purposes (Kabilan, Ahmad, and Zainol, 2010). In addition, Datuk Seri Mohd Khaled Nordin, the Minister of Higher Education in Malaysia also welcome and encourage the use of social networking websites such as Facebook and Twitter for educational Purposes (New Straits Times, 2012) due to its effectiveness in spreading massages and getting faster responses compared to official portals or other learning platforms utilized by universities.

However, due to some scholars perceptions that Facebook and any web 2.0 tools are not appropriate for teaching and learning purposes (Waycott, Bennett, Kennedy, Dalgarno \& 
Gray, 2010; Salaway Caruso \& Nelson, 2007; Lohnes and Kinzer, 2007), there have not been many studies investigating the use of social networking sites like MySpace, Ning, Google Plus+, LinkedIn and other social networking sites (Lockyer and Patterson, 2008) especially Facebook. Despite its frequency of use globally, FB still has not been widely used in tertiary education (McCarthy, 2010). In this study, a feasible attempt was made in order to enhance students' learning performance. Therefore, Facebook was employed in writing activities for second year students majoring in English as Second Language to gauge whether there was a significant difference or not in the writing performance as compared to the conventional group.

\section{Literature Review}

Online learning has a strong connection with social learning theories which heavily influenced by social constructivism theory (Hrastinski, 2009). Barnard and Campbell (2005) believe that social and cultural cannot be separated in the journey of exploring human's learning. In socialcultural learning theory, interaction between learners in a specific context via feedback and instructions from others that leads to opportunities to learn is the main backbone of this theory. Social constructivists believe that higher mental functions are developed through the signs and symbols (Gredler, 1997). Hence relationships formed among social, cultural and historical in any learning context inbuilt communication shape what is learned and how it is learned. Social context is the most pivotal criteria in this theory where learning process and cognition role consume their part (Vygotsky, 1978). In this context, Facebook is seen as a perfect platform because it has criteria that fit with social cultural theory because knowledge can be fostered and developed via collaboration, negotiation, active participation, identity construction as well as community building. Through online community, meaningful education experiences, dynamic interactions, higher order thinking and knowledge construction can be sustained (Garrison and Kanuka, 2004). Therefore, social media platform like Facebook has attracted users especially students to become avid users and also motivated them to participate in learning activities. Students nowadays have experienced interesting learning process in comparison to previous years via social networking sites such as Twitter, video sharing (Instagram, Youtube, Keek) (Schroeder et al. 2010; Ebner et al. 2010; Grosseck \& Holotescu; Rankin 2009) and latest addiction is the Facebook.

In this study, the researcher had attempted a series of writing activities in second language learning using cognitive theory proposed by Flower and Hayes (1981). Flower and Hayes (1981) has proposed a guideline for writers to use when producing writing outcomes. Their guideline consists of planning, drafting and reviewing. This theory was further expanded by Byrne (1988). Byrne (1988) has further modified the writing process into five part such as gathering ideas, preparing an outline ('scaffolding'), writing a draft, correcting and improving the draft and writing the final output. Originally, Flower and Hayes's (1981) guideline was designated for individual authors. However, Neuwirth, Kaufer, Chandhok and Morris (1994) suggested that it is also applicable for many writers who work collectively.

Collaborative writing can be assisted with the suggested guideline. This is pivotal as collaboration is perceived as an attempt to reach mutual consensus which by far is better than 
individual understanding (Wells, 2000). Through collaboration, learning can be enhanced as a result of the act of 'doing things together, negotiating new meaning and learning from each other (Wenger, 1998). Knowledge is developed and re-created by a group of people with the aim of achieving common goals or overlapping purposes (Wells, 2000; Wenger, 1998; Lave and Wenger, 1991; Freire, 1970). Having utilized collaborative activities in social networking site such as Facebook with collaboration elements via comment and files applications has stepped up learning into a whole new level. Students can experience an online learning platform that could boost their confidence in language acquisition and a sense of connectedness among them (Wang \& Chen, 2007). In the online learning platform, students are immersed and surrounded with rich and authentic information as a result from social interaction. Wenger, McDemrmott \& Synder, 2002) also agree that English language learning is facilitated better via Facebook because it allows students to improve learning and get interconnected within the Facebook communities. Kabilan, Ahmad and Zainol (2010) also support that with proper planning in an educational project, Facebook could allow for a more positive effect of meaningful English learning. Nadzrah \& Mickan (2003) assert that students can use the language without worrying about language mistakes hence making them to become more optimistic to engage in Facebook. Through the use of Facebook in collaborative writing activities, students are able to have discussion and conversation virtually and share their ideas, comments and opinions in completing their writing assignments, which are aligned with sociocultural theory. Cognitive theory by Flower and Hayes (1981) has become the guideline in assisting students to write collaboratively via Facebook.

In summary, social interaction, technology and pedagogy are the key factors for computer assisted language learning. Therefore, the author had utilized Facebook in collaborative writing activities for ESL undergraduates in order to improve their language learning in particular English writing as well as gauging their satisfaction. The purpose of this study was to investigate the effects of Facebook collaborative groups on ESL students' writing performance.

\section{Methodology}

A total of 33 second year ESL undergraduates ( 9 males, 24 females) from Universiti Putra Malaysia were chosen as the respondents of the study. The participants were divided into treatment group (4 males, 12 females) and comparison group (5 males, 12 females) using systematic random sampling based on the pre-test results. Then, the author had arranged the pre-test results in descending order and paired the highest scores with the lowest scores. This was to determine the collaborative writing groups for both comparison and treatment groups. For the comparison group, the participants were required to do the writing tasks via face-to-face method. Meanwhile, in the treatment group the participants were required to join Facebook groups created by the author called 'Pour Your Thoughts 1 - Pour Your Thoughts 4'. Before going through different treatments, the participants were taught by the author in two meetings and the rest of the writing activities were conducted for six consecutive weeks. Prior to the treatment, the participants were given a pre-test and post test of argumentative essays taken from Educational Testing Service (ETS) question's bank and an analytic rubric 
by Jacob's (1981) ESL Composition Profile. The elaborations are as follows:

\subsection{Writing Tests}

After considering participants' gender, religion and background, standardized topics were chosen from Educational Testing Service (ETS) in order to avoid biasness. Argumentative writing was chosen because it was the most common type of essay used in determining writing performance (Nussbaum, 2005; Midgette, Haria and MacArthur, 2008). Besides, the test was employed due to its nature that required further discussion in conveying the desired goal (Coirier, Andriessen \& Chanquoy, 1999).

\subsection{Writing Scale}

Another instrument that was employed was an analytic rubric by Jacob's et al. (1981) ESL Composition Profile. This rubric is the most used for evaluating ESL writing (Bailey, 1998) and considered as a complete rubric which was able to assess all important elements of writing (Lam and Pennington, 1993). Besides, this rubric also is suitable to be used by inexperienced raters (Francis, 1988; Adam, 1981, cited in Wier, 1993). Additionally, analytic rubric was chosen as compared to holistic scoring because it is deemed more reliable and more useful especially for second-language learners with different writing aspects such as marked or uneven profile (Hamp-Lyons, 1991; Huot, 1996). This rubric was utilized throughout the study beginning from pre-test to post-test stages by both raters.

\section{Findings and Discussion}

\subsection{Results of the pre-test and post-test of English Writing}

Table 1. Pre-test Results of English writing between face-to-face and Facebook collaborative writing groups

\begin{tabular}{|c|c|c|c|c|c|}
\hline Pre-test & Method & Mean & SD & t & $p$ \\
\hline \multirow{2}{*}{ Content } & Face-to-face & 19.56 & 2.66 & \multirow{2}{*}{.926} & \multirow{2}{*}{.362} \\
\hline & \begin{tabular}{|l|} 
Facebook \\
\end{tabular} & 20.47 & 2.98 & & \\
\hline \multirow{2}{*}{ Organization } & Face-to-face & 14.32 & 2.42 & \multirow{2}{*}{.482} & \multirow{2}{*}{.633} \\
\hline & Facebook & 14.69 & 1.86 & & \\
\hline \multirow{2}{*}{ Vocabulary } & Face-to-face & 13.09 & 2.41 & \multirow{2}{*}{1.126} & \multirow{2}{*}{.269} \\
\hline & Facebook & 13.97 & 2.06 & & \\
\hline \multirow{2}{*}{ Language Use } & Face-to-face & 15.12 & 3.05 & \multirow{2}{*}{-.477} & \multirow{2}{*}{.637} \\
\hline & Facebook & 14.63 & 2.87 & & \\
\hline \multirow{2}{*}{ Mechanics } & Face-to-face & 2.94 & 2.94 & \multirow{2}{*}{.504} & \multirow{2}{*}{.618} \\
\hline & Facebook & 3.03 & 3.03 & & \\
\hline \multirow{2}{*}{ Total } & Face-to-face & 65.03 & 10.27 & \multirow{2}{*}{.480} & \multirow{2}{*}{.634} \\
\hline & Facebook & 66.66 & 9.108 & & \\
\hline
\end{tabular}

$p<.05$

In Table 1, the pre-test results between the face-to-face collaborative writing groups and the Facebook collaborative writing group indicated that there was no significant difference before 
the intervention in terms of content, organization, vocabulary, language use as well as mechanics. From the independent sample t-test results, the significant values were >.05. Therefore, the alternative hypotheses were rejected and the null hypotheses were accepted showing that there was no significant difference between the groups' pre-test.

Table 2. Post-test Results of English writing between face-to-face and Facebook collaborative writing groups

\begin{tabular}{|c|c|c|c|c|c|}
\hline Post-test & Method & Mean & SD & $\mathbf{t}$ & $p$ \\
\hline \multirow{2}{*}{ Content } & Face-to-face & 23.67 & 2.36 & \multirow{2}{*}{1.213} & \multirow{2}{*}{.234} \\
\hline & Facebook & 24.59 & 1.94 & & \\
\hline \multirow{2}{*}{ Organization } & Face-to-face & 16.09 & 1.46 & \multirow{2}{*}{1.138} & \multirow{2}{*}{.264} \\
\hline & Facebook & 16.63 & 1.23 & & \\
\hline \multirow{2}{*}{ Vocabulary } & Face-to-face & 15.09 & 1.57 & \multirow{2}{*}{.392} & \multirow{2}{*}{.698} \\
\hline & Facebook & 15.34 & 2.14 & & \\
\hline \multirow{2}{*}{ Language Use } & Face-to-face & 16.74 & 2.56 & \multirow{2}{*}{.302} & \multirow{2}{*}{.765} \\
\hline & Facebook & 17.00 & 2.47 & & \\
\hline \multirow{2}{*}{ Mechanics } & Face-to-face & 3.11 & .38 & \multirow{2}{*}{1.752} & \multirow{2}{*}{.090} \\
\hline & Facebook & 3.38 & .47 & & \\
\hline \multirow{2}{*}{ Total } & Face-to-face & 74.71 & 7.59 & \multirow{2}{*}{.867} & \multirow{2}{*}{.393} \\
\hline & Facebook & 76.94 & 7.18 & & \\
\hline
\end{tabular}

$p<.05$

In Table 2, the independent t-test of the post test scores indicated that there was no significant difference between face-to-face and Facebook collaborative writing groups in terms of content, organization, vocabulary, language use as well as mechanics. Additionally, in terms of overall writing performance, there was also no significant differences between face-to-face collaborative writing group and Facebook collaborative writing group.

Table 3. Comparison of Pre-test and Post-test Scores of Overall Writing Performance for Face-to-Face collaborative writing groups

\begin{tabular}{|c|c|c|c|c|}
\hline Face-to-face & Mean & SD & $\mathbf{t}$ & $p$ \\
\hline Pre-overall performance & 65.03 & 10.27 & \multirow{2}{*}{-3.52} & \multirow{2}{*}{.003} \\
\hline Post-overall performance & 74.71 & 7.59 & & \\
\hline Pre-content & 19.56 & 2.66 & \multirow{2}{*}{-5.69} & \multirow{2}{*}{.000} \\
\hline Post-content & 23.68 & 2.36 & & \\
\hline Pre-organization & 14.32 & 2.42 & \multirow{2}{*}{-2.74} & \multirow{2}{*}{.014} \\
\hline Post-organization & 16.09 & 1.46 & & \\
\hline Pre-vocabulary & 13.09 & 2.41 & \multirow{2}{*}{-3.54} & \multirow{2}{*}{.003} \\
\hline Post-vocabulary & 15.09 & 1.57 & & \\
\hline
\end{tabular}




\begin{tabular}{|l|c|c|c|c|}
\hline Pre-language use & 15.12 & 3.05 & \multirow{2}{*}{-1.73} & \multirow{2}{*}{.102} \\
\hline Post-language use & 16.74 & 2.56 & & \\
\hline Pre-mechanics & 2.94 & .46 & \multirow{2}{*}{-2.56} & .138 \\
\hline Post-mechanics & 3.12 & .38 & & \\
\hline
\end{tabular}

*rounded off to the nearest number

In Table 3, there were significant differences before and after intervention for the face-to-face collaborative writing groups in overall scores, content, organization and vocabulary. However, for the language use and mechanics, there were no significant differences because the significant values $p>.05$.

Table 4. Comparison of Pre-test and Post-test Scores of Overall Writing Performance for Facebook collaborative writing groups

\begin{tabular}{|c|c|c|c|c|}
\hline Facebook & Mean & SD & $\mathbf{t}$ & $p$ \\
\hline Pre-overall performance & 66.66 & 9.11 & \multirow{2}{*}{-6.86} & \multirow{2}{*}{.000} \\
\hline Post-overall performance & 76.94 & 7.18 & & \\
\hline Pre-content & 20.47 & 2.98 & \multirow{2}{*}{-8.04} & \multirow{2}{*}{.000} \\
\hline Post-content & 24.59 & 1.94 & & \\
\hline Pre-organization & 14.69 & 1.86 & \multirow{2}{*}{-5.73} & \multirow{2}{*}{.000} \\
\hline Post-organization & 16.63 & 1.23 & & \\
\hline Pre-vocabulary & 13.97 & 2.06 & \multirow{2}{*}{-3.08} & \multirow{2}{*}{.008} \\
\hline Post-vocabulary & 15.34 & 2.14 & & \\
\hline Pre-language use & 14.63 & 2.87 & \multirow{2}{*}{-3.30} & \multirow{2}{*}{.005} \\
\hline Post-language use & 17.00 & 2.47 & & \\
\hline Pre-mechanics & 3.03 & .56 & \multirow{2}{*}{-2.71} & \multirow{2}{*}{.016} \\
\hline Post-mechanics & 3.34 & .46 & & \\
\hline
\end{tabular}

*rounded off to the nearest number

In Table 4, from the paired sample t-test analysis, it was found that there were significant differences in terms of overall performance as well as five components of Jacobs et al. (1981) ESL Composition Profile. This indicates that Facebook collaborative writing group had improved students writing performance after the intervention. However, Facebook collaborative writing groups obtained higher scores compared to face-to-face collaborative writing groups. This shows that social networking platforms like Facebook increased students' writing ability and helped them performed better (Roberts, 2009; Thanawan and Punchalee, 2012; Hatime \& Zaynep, 2012; Wichadee and Nopakun, 2012) compared to face-to-face method. Blattner and Fiori (2009) emphasizes that authentic language interaction can be achieved via the interaction in Facebook which boosts students' confidence level and improve their English language performance. Learners were allowed to express themselves in a more expressive manner without worrying about committing language mistakes (Nadzrah \& Mickan, 
2003). With proper planning in educational project, English language learning could be established through Facebook (Kabilan et. al 2010). Facebook also believed to be an ideal place for learners to be surrounded by the language (Pasfield-Neofitou, 2011).

\section{Conclusion}

Overall, it can be said that students' writing performance was improved with the use of Facebook in collaborative writing. With Facebook, more meaningful learning environment can be created and comment feature makes the learning process more easy and fun. Facebook also allows students to discuss with peers, give feedback and comment on the writing activities either synchronous or asynchronously. Therefore, these findings may be beneficial for stakeholders, educators or writing instructors to utilize collaborative writing in Facebook especially to harness writing skills and change students' perceptions that Facebook is actually appropriate to be medium for English learning. Besides, this study also is hoped to make them to see the connection between the meaningful communicative use outside of the classroom and writing activities that were conducted in a formal setting like classroom context. It is recommended that for future research, a comparison between Facebook and other social networking sites such as Wikis or Ning should be made to ascertain which platform is more suitable and effective in improving writing performance. Additionally, a qualitative research also can be conducted in identifying the writing process involved in terms of language structure, writing style, tone and the likes.

\section{References}

Ashton, J., \& Newman, L. (2006). An unfinished symphony: 21st century teacher education using knowledge creating heutagogies. British Journal of Educational Technology, 37(6) 825-840. http://dx.doi.org/10.1111/j.1467-8535.2006.00662.x.

Barnard, R., \& Campbell, L. (2005). Sociocultural theory and the teaching of process writing: The scaffolding of learning in a university context. The TESOLANZ Journal, 13, 76-88.

Biggs, J. (1987). Student approaches to learning and studying. Hawthorne, Vic.:ACERo.

Blattner, G., \& Fiori, M. (2009). "Facebook in the language classroom: Promises and Possibilities." International Journal of Instructional Technology and Distance Learning, 6(1). Retrieved on May 5, 2012 from http://www.itdl.org/journal/jan_09/article02.htm

Byrne, D. (1988). Teaching Writing Skills. Harlow: Longman.

Ebner M., Lienhardt C., Rohs M. \& Meyer I. (2010) Microblogs in higher education- a chance to facilitate informal and process-oriented learning. Computers \& Education, 55, 92-100. forthcoming.

Flower, L., \& Hayes, J. R. (1981). College Composition and Communication. Vol. 32, No. 4. pp. 365-387. Retrieved May 2013, 22 from http://www.jstor.org/stable/356600

Freire, P. (1970). Pedagogy of the oppressed. New York, NY: Seabury Press

Garisson, R., \& Kanuka, H (2004). Blended learning: Uncovering transformative potential in 
higher education. Internet and Higher Education, 7(2), 95-105.

Gredler, M. E. (1997). Learning and instruction: Theory into practice (3rd ed). Upper Saddle River, NJ: Prentice-Hall.

Grosseck G., \& Holotescu C. (2009) Can we use Twitter for educational activities?Proceedings of the 4th International Scientific Conference: eLearning and Softwarefor Education, Bucharest, Romania. Retrieved December 2012, 12, from: http://adlunap.ro/eLSE_publications/papers/2008/015.-7.1.Grosseck\%20Gabriela-Can\%20we \%20use.pdf

Hatime, C., \& Zeynep, K. (2012). Effects of Peer E-Feedback on Turkish EFL Students' Writing Performance. The Journal of Educational Computing Research, 46(1), 61-84.

Hrastinski, S. (2009). A theory of online learning as online participation. Computers and Education, 52, 78-82. Vygotsky, L. S. (1978).

Kabilan. M. K,. Ahmad, N., \& Zainol Abidin, M. J. (2010). Facebook: An onlineenvironment for learning of English in institutions of higher education?. Internet and Higher Education, $13,179-187$.

Kessler, G. (2009). Student-Initiated Attention to Form in Wiki-Based Collaborative Writing. Language Learning \& Technology. Volume 13, Number 1, pp. 79-95. Retrieved 15 March 2012, from http://1lt.msu.edu/vol13num1/kessler.pdf

Kwong, V. (2007). Reach out to your students using MySpace and Facebook. Indiana Libraries, 26(3), 53-57.

Lave, J., \& Wenger, E. (1991). Situated learning: Legitimate peripheral participation. New York, NY: Cambridge University Press.

Lohnes, S., \& Kizer, C. (2007). "Questioning Assumptions about Students Expectations for Technology in College Classrooms." Innovate. Volume 3, Issue 5. Retrieved September 26, 2012

from http://www.innovateonline.info/pdf/vol3_issue5/questioning_assumptions_about_students\%2 7_expectations_for_technology_in_college_classrooms.pdf

McCarthy, J. (2010). Blended learning environments: Using social networking sites to enhance the first year experience. Australasian Journal of Educational Technology, 26(6), 729-740. $\quad$ Retrieved $\quad$ September $29, \quad 2012$ from http://www.ascilite.org.au/ajet/ajet26/mccarthy.html

McLoughin, C., \& Lee, M. (2007). Social software and participatory learning: Pedagogical choices with technology affordances in the Web 2.0 area.

Midgette, E., Haria, P., \& MacArthur, C. (2008). The effect of content and audience awareness goals for revision on the persuasive essays of fifth-and eighth-grade students. Reading and Writing: an interdisciplinary journal, 21, 1-2, 131-51.

Mohd Khaled Nordin (2012, February 23). Khaled: Use Facebook in varsities. New Straits 
Times. $\quad$ Retrieved

February

2012

28 ,

from:

http://www.nst.com.my/latest/khaled-use-Facebook-in-varsities-1.50763

Nadzrah, A. B., \& Mickan, P. (2003). Students' experiences in computer-based English language classroom. Proceedings of the 2003 ASIA CALL Conference. Gyeongju University, South Korea: ASIACALL.

Neuwirth, C. M., Kaufer, D. S., Chandhok, R., \& Morris, J. H. (1994). Computer support for distributed collaborative writing: Defining parameters of interaction. In Proceedings of the Conference on Computer-Supported Cooperative Work (CSCW'94), (pp. pp. 145-152). Oct. 22-26, Chapel Hill, NC: Association for Computing Machinery.

Nussbaum, E. M. (2005). The effect of goal instructions and need for cognition on interactive argumentation. Contemporary Educational Psychology, 30, 286-313.

Pasfield-Neofitou, S. (2011). Online domains of language use: second language learners' experiences of virtual community and foreignness. Language Learning \&Technology, 15(2), 92-108.

Rankin M. (2009). Some general comments on the „Twitter experiment." Web post by Monica Rankin. Available at: Retrieved May 29, 2012, http://www.utdallas.edu/ mrankin/usweb/twitterconclusions.htm.

Roberts, W. G. (2009). Facebook Interactions and Writing Skills of Spanish Language Students. Thesis. Concordia College.

Salaway, G., Caruso, J. B., \& Nelson, M. R. The ECAR Study of Undergraduate Students and Information Technology, 2007. Boulder, Colo.: EDUCAUSE, 2007. Retrieved September 27, 2012

from

http://www.educause.edu/library/resources/ecarstudy-undergraduate-students-and-informatio n-technology-2007

Saovapa Wichadee, \& Pornrape Nopakun (2012). The Effects of Peer Feedback on Students ${ }^{\text {ee }}$ Writing Ability. European Journal of Social Sciences. Vol. 33 No 3 September, pp. 393-400.

Schroeder A., Minocha S., \& Schneider C. (2010). The strengths, weaknesses, opportunities, and threats of using social software in higher and further education teaching and learning. Journal of Computer Assisted Learning, 26, 159-174.forthcoming.

Selwyn, N. (2009). Faceworking: Exploring students" education-related use of Facebook. Learning, Media \& Technology, 34(2), 157-174. http://dx.doi.org/10.1080/17439880902923622

Simons, P. R.-J. (1992). Constructive learning: The role of the learner. In T. M. Duffy, J. Lowyck, D. Jonassen, \& T. M. Welsh (Eds), Designing environments for constructive learning (pp. 291-313). Berlin: Springer-Verlag.

Thanawan Suthiwartnarueput, \& Punchalee Wasanasomsithi (2012). Effects of Using Facebook as a Medium for Discussions of English Grammar and Writing of 
Low-Intermediate EFL Students. Electronic Journal of Foreign Language Teaching 2012, Vol 9, No. 2, pp. 194-214. Retrieved 13 May 2013, from http://eflt.nus.edu.sg/v9n22012/suthiwartnarueput.pdf.

Vygotsky, L. (1978). Mind in Society. London: Harvard University Press

Wang, Y., \& Chen, N. (2007). Online synchronous language learning: SLMS over the Internet. Innovate, 3(3), 1-7 www.innovateonline.com.

Waycott, J., Bennett, S., Kennedy, G., Dalgarno, B., \& Gray, K. (2010). Digital divides? Student and staff perceptions of information and communication technologies. Computers \& Education, 54(4), 1202-1211.

Wells, G. (2000). Dialogic inquiry in education. Building on the legacy of Vygotsky. In C. Lee, \& P. Smagorinsky (Eds.), Vygostkian perspectives on Literacy research. Constructing meaning through collaborative inquiry (pp. 51-85). Cambridge, UK:Cambridge University Press.

Wenger, E. (1998). Communities of Practice: Learning, Meaning, and Identity. Cambridge, MA: Harvard University Press.

Wenger, E., McDermott, R., \& Snyder, W. M. (2002). Cultivating communities of practice: A guide to managing knowledge. Boston, MA: Harvard Business School Press.

Zimmerman, B. J., \& Schunk, D. H. (Eds) (1989). Self-regulated learning and academic achievement: Theory, research and practice. New York: Springer-Verlag.

\section{Copyright Disclaimer}

Copyright for this article is retained by the author(s), with first publication rights granted to the journal.

This is an open-access article distributed under the terms and conditions of the Creative Commons Attribution license (http://creativecommons.org/licenses/by/3.0/). 